\title{
Relaxin in peripheral plasma of boars during development, copulation, after administration of hCG and after castration
}

\author{
H. H. Juang ${ }^{1 *}$, A. I. Musah ${ }^{1 \dagger}$, C. Schwabe ${ }^{2}$, J. J. Ford ${ }^{3}$ and \\ L. L. Anderson ${ }^{1 \ddagger}$ \\ ${ }^{1}$ Department of Animal Science, Iowa State University, Ames, IA 50011, USA; ${ }^{2}$ Department of \\ Biochemistry, Medical University of South Carolina, Charleston, SC 29495, USA; and \\ ${ }^{3}$ Roman L. Hruska US Meat Animal Research Center, Clay Center, NE 68933, USA
}

\begin{abstract}
Seventy-two Yorkshire boars were used in five experiments to evaluate the temporal changes in relaxin concentrations in peripheral blood plasma during prepubertal development, copulation, after castration and after treatment with hCG. High concentrations of relaxin $\left(484 \pm 27 \mathrm{pg} \mathrm{ml}^{-1}\right)$ were detected at 11 weeks of age but there was no positive correlation with testicular development. Relaxin concentrations fluctuated in mature boars but the results do not suggest a diurnal rhythm, although there is the possibility of pulsatile secretion. A decrease $(P<0.05)$ in circulating relaxin was observed before and immediately after copulation. Castration of boars at 90, 115, 160 and 200 days of age did not significantly decrease relaxin concentrations within $48 \mathrm{~h}$. Administration of hCG significantly depressed relaxin secretion at 90 days of age but not at 160 days of age. These studies suggest a non-gonadal source of boar relaxin that is not correlated with testicular growth or testosterone concentrations, is modulated by copulation and by hCG but only at specific stages of development.
\end{abstract}

\section{Introduction}

Relaxin, a $6 \mathrm{kDa}$ peptide hormone, has been found primarily in reproductive tissues and circulating blood during pregnancy and parturition in females of several mammals but is also found in the male reproductive tract (Anderson, 1987; Weiss, 1989). Relaxin-like immunoactivity was detected in human and boar semen (Weiss et al., 1986; Juang et al., 1990). Porcine relaxin was shown to have a specific effect on improving the motility of human and boar spermatozoa (Lessing et al., 1986; Juang et al., 1989) and the fertilization capacity of human and mouse spermatozoa (Pupula et al., 1986; Park et al., 1988). The presence of relaxin in the male reproductive tract of rats, mice and humans is, however, still controversial (Kendall et al, 1982; Yki-Jarvinen et al., 1983; Anderson et al., 1986). In boars, a relaxin-like immunocytological reaction was reported in interstitial and Sertoli cells of the testes (Dubois and Dacheux, 1978), and the presence of mRNA encoding relaxin was demonstrated in Leydig cells and in the prostate gland using reverse transcription and the polymerase chain reaction (Lobb and Porter, 1995; Lobb et al., 1995). Kohasaha et al. (1992) found relaxin cytoplasmic immunoreactivity in boar seminal vesicles. There is little information about the physiological role

\footnotetext{
*Present address: Chang Gung College of Medicine and Technology, Department of Anatomy, 259 Wen-Hua Ist Road, Kwei-Shan, Tao-Yuan, Taiwan, Republic of China.

tPresent address: St Cloud State University, Department of Biological Sciences, 720 Fourth Avenue South, St Cloud, MN 56301, USA.

\$Reprint requests.

Received 3 October 1995.
}

of relaxin in the male. In this study, the correlation between changes in relaxin concentrations in plasma and testicular development, and aspects of the physiological regulation of relaxin secretion were determined in the boar.

\section{Materials and Methods}

\section{Animals and blood sample collection}

Yorkshire boars were fitted with an indwelling cannula (i.d. $0.125 \mathrm{~cm}$; o.d. $0.225 \mathrm{~cm}$; Tygon microbore tubing, no. 14-170-5E, Fisher Scientific Co., Itasca, IL) inserted into the external jugular vein as described by Ford and Maurer (1978). Blood samples were collected into heparinized (143 U heparin) Vacutainer tubes (no. 02-685-3B, Fisher Scientific Co.) and centrifuged immediately at $2000 \mathrm{~g}$ for $15 \mathrm{~min}$. Plasma was stored at $-20^{\circ} \mathrm{C}$ until hormone assay. Twenty-six Yorkshire boars born within 6 weeks were weaned at 4 weeks of age and moved to an environmentally controlled nursery room in the pig research building (Animal Reproduction Laboratory, Iowa State University). After weaning, all boars remained in the nursery until 9 weeks of age; then they were moved to the finishing building and penned in the same stall. Boars were housed in the same building with same-age females throughout the study but were segregated by sex.

\section{Experimental protocols}

Experiment 1. Blood samples $(3 \mathrm{ml})$ were obtained once a week from boars $(n=26)$ from birth to 3 weeks of age. At 5 to 
29 weeks of age, sequential blood samples were obtained at intervals of 2 weeks from six boars. Six other boars were used to obtain sequential blood samples at intervals of 2 weeks between 5 and 29 weeks after birth. Blood samples were obtained by venepuncture of the anterior vena cava.

Experiment 2 (sequential sampling over $24 \mathrm{~h}$ ). Two days before the experiment, three sexually mature ( $>1.5$ years of age) and two prepubertal (115 days of age) boars were confined in individual crates in a controlled-climate room $\left(26^{\circ} \mathrm{C}\right)$ with a $12 \mathrm{~h}$ light:12 h dark (lights on 07:00-19:00 h) lighting regimen. Boars were isolated from females during this period. Blood samples $(7 \mathrm{ml})$ were collected every hour for $24 \mathrm{~h}$ except during 09:00-12:00 $\mathrm{h}$ and 21:00-23:00 $\mathrm{h}$ when blood was collected at intervals of $15 \mathrm{~min}$.

Experiment 3 (after castration). Boars were castrated at different developmental stages (90 days $(n=4), 115$ days $(n=2), 160$ days $(n=4)$ and 200 days $(n=6))$. An indwelling cannula was implanted into the external jugular vein, as described previously, 5 days before castration. For castration, anaesthesia was induced and maintained with an i.v. injection of thiamylal sodium (0.3-0.6 g; Surital; Parke-Davis, Morris Plains, NJ). Testes and epididymides were removed surgically, trimmed of excess tissue and weighed separately. All animals were weighed before castration. Blood samples $(7 \mathrm{ml})$ were obtained $\mathrm{Ih}$ before $(-1)$ and $0.5,6,24$ and $48 \mathrm{~h}$ after castration, and the plasma was collected for hormone assay.

Experiment 4 (during copulation). Three mature Yorkshire boars (about 18 months old) were evaluated for the effect of copulation and ejaculation on the concentration of relaxin in peripheral plasma. A Tygon microbore external jugular cannula was implanted 2 days before the experiment for collection of blood before, during and after mating. Boars were confined in individual crates inside a controlled-climate room $\left(26^{\circ} \mathrm{C}\right)$ with a $12 \mathrm{~h}$ light: $12 \mathrm{~h}$ dark (lights on 07:00-19:00 h) lighting regimen. Boars were isolated from females during this period. The effect of male sexual behaviour and copulation on relaxin secretion was continuously monitored in these three boars. Oestrous gilts were penned separately in the same room with the boar for $1 \mathrm{~h}$ before mating, and three blood samples were obtained at intervals of 20 min from each boar during this period of aggressive sexual behaviour. During mating, an additional blood sample was collected. All gilts were removed immediately after mating, and sequential blood samples $(7 \mathrm{ml})$ were withdrawn from the indwelling jugular catheters every $10 \mathrm{~min}$ for the first $1 \mathrm{~h}$ and every $20 \mathrm{~min}$ for the subsequent $3 \mathrm{~h}$.

Experiment 5 (after administration of $h C G$ ). Sixteen Yorkshire boars were assigned randomly to one of four i.m. treatments: saline $(3 \mathrm{ml})$ control administered on day $90(n=4)$; hCG (4000 iu; Follutein; Solvay Veterinary Inc., Princeton, NJ) administered on day $90(n=4)$; saline control administered on day $160(n=4)$ and hCG (4000 iu) administered on day 160 $(n=4)$. These animals were weaned at 4 weeks of age. The boars were moved to the finishing building and penned together after 9 weeks of age. During rearing, they were maintained in all-male groups but were never isolated from possible audible and pheromonal stimuli of contemporary females.

The boars were moved to individual pens, and 2 days later they were fitted with an indwelling jugular cannula and they subsequently received hormone and saline treatments. Anaesthesia was induced by an injection of thiamylal sodium (0.3-0.6 g; Surital, Parke-Davis) into an ear vein and maintained by a closed-circuit system of halothane $(3-10 \%$, Ayerst Laboratories, Rouses Point, NY) and oxygen $(400-1000 \mathrm{cc}$ $\mathrm{ml}^{-1}$ ) during surgery. The indwelling jugular catheter was implanted as described previously. Blood samples were collected every hour for $3 \mathrm{~h}$ before treatment and during the first $10 \mathrm{~h}$ after hormone or saline administration; thereafter, samples were collected at intervals of $2 \mathrm{~h}$ for up to $80 \mathrm{~h}$ after treatment.

\section{Radioimmunoassay of relaxin in peripheral plasma}

Relaxin concentrations in peripheral blood plasma of boars were quantified in duplicate aliquots of $200 \mu$ l by using a homologous radioimmunoassay for porcine relaxin as described by Li et al. (1989) and Juang et al. (1990). Monotyrosyl relaxin ( $3000 \mathrm{U} \mathrm{mg}^{-1}$ ) was iodinated by a modified version of the chloramine-T procedure (Schwabe, 1983). Plasma samples $(200 \mu \mathrm{l})$ were quantified by a double antibody radioimmunoassay. After addition of $300 \mu \mathrm{l} 0.01 \mathrm{~mol}$ PBS $1^{-1}-1 \%$ BSA (w/v) buffer, $100 \mu \mathrm{l}$ anti-porcine relaxin antibody (Dual Rabbit $R_{6}$ from B. G. Steinetz, New York University, Tuxedo, NY) diluted 1:20 000 in 0.01 mol PBS $1^{-1}-1 \%$ BSA containing

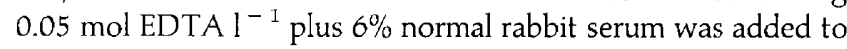
each tube. Tubes were incubated for $24 \mathrm{~h}$ at $4^{\circ} \mathrm{C}$; then, $100 \mu \mathrm{l}$ ${ }^{125}$ I-labelled porcine relaxin $(9500-12000$ c.p.m. in $0.01 \mathrm{~mol}$ PBS $1^{-1}-1 \%$ BSA) was added to all tubes. After incubation for $48 \mathrm{~h}$ at $4^{\circ} \mathrm{C}, 200 \mu \mathrm{l}$ 1:10 goat antirabbit IgG (no. 0112-0081, Organon Teknika Co., West Chester, PA) was added to each tube and they were then incubated for another $18-24 \mathrm{~h}$ at $4^{\circ} \mathrm{C}$. Three millilitres $0.01 \mathrm{~mol} \mathrm{PBS} \mathrm{I}^{-1}-1 \%$ BSA was then added to each tube and the tubes were centrifuged at $2200 \mathrm{~g}$ for $30 \mathrm{~min}$; the supernatant was decanted, and the precipitate was counted in a $\gamma$-counter (Packard Cobra Autogamma 5003). Parallelism was established by testing different volumes of blood plasma. The maximum binding and nonspecific binding of the antibody were $35.5 \pm 3.4 \%$ and $3.6 \pm 0.4 \%(n=4)$, respectively. The intra- and interassay variabilities were $6.5 \%$ and $6.7 \%$, respectively. The sensitivity of the assay was $27 \mathrm{pg}$ per tube.

\section{Radioimmunoassay of testosterone in peripheral plasma}

Testosterone concentrations in peripheral blood were determined in duplicate $10-200 \mu \mathrm{l}$ aliquots of plasma by radioimmunoassay as described by Ford et al. (1980). A rabbit antiserum prepared against testosterone-7 $\alpha-B S A$ (no. 61-315, Lot TT-2, Miles-Yeda Ltd, Naperville, IL) was used in this assay and had less than $17 \%$ crossreactivity with $5 \alpha$-dihydrotestosterone. Plasma samples were extracted twice by mixing with ethyl ether for $15 \mathrm{~min}$, freezing and then decanting the ethyl ether. Recovery was on average greater 
Table 1. The average body mass and testes and epididymides masses during development in Yorkshire boars

\begin{tabular}{lcccc}
\hline & \multicolumn{4}{c}{ Age (days) } \\
\cline { 2 - 5 } Parameter & $\begin{array}{c}90 \\
(n=8)\end{array}$ & $\begin{array}{c}115 \\
(n=2)\end{array}$ & $\begin{array}{c}160 \\
(n=7)\end{array}$ & $\begin{array}{c}200 \\
(n=6)\end{array}$ \\
\hline Body (kg) & $33 \pm 3.3$ & $41 \pm 11.4$ & $93 \pm 7.7$ & $116 \pm 6.3$ \\
Testes (g) & $35 \pm 5.8$ & $50 \pm 12.8$ & $262 \pm 22.6$ & $322 \pm 31.5$ \\
Epididymides (g) & $16 \pm 1.1$ & $28 \pm 4.6$ & $100 \pm 15.7$ & $91 \pm 22.7$ \\
\hline
\end{tabular}

Values are means \pm SEM.

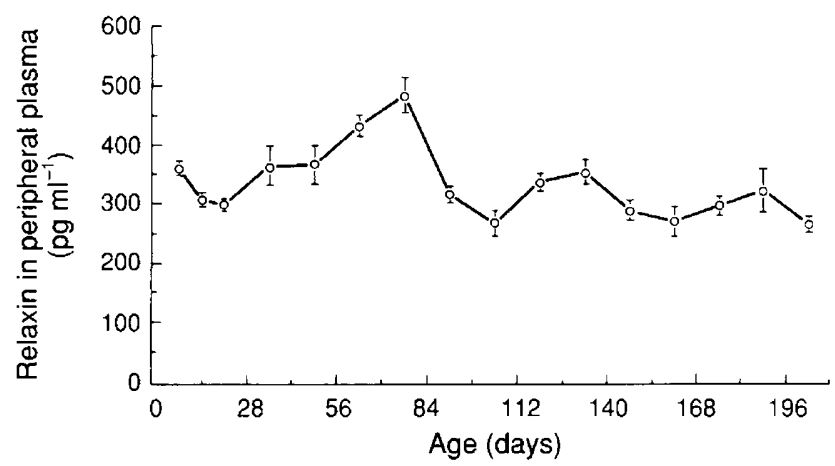

Fig. 1. Peripheral plasma concentrations of relaxin during prepubertal development and puberty in Yorkshire boars $(n=26)$. Blood samples were obtained at weekly intervals for 3 weeks after birth and at intervals of 2 weeks between 5 and 29 weeks. Values are means \pm SEM.

than $90 \%$, and the samples were not corrected for procedural losses. Parallelism was established by testing different volumes of plasma. Sensitivity of the assay was $5 \mathrm{pg}$ per tube. A pool of boar plasma was included in each of the five assays and had a mean of $1.7 \mathrm{ng} \mathrm{ml}^{-1}$, with an interassay coefficient of variance of $7.1 \%$. The intra-assay coefficient of variance was $8.6 \%$.

\section{Statistical analyses}

Experimental units in this study were the individual boars, and they were assigned to treatment groups at random. Data were analysed by using a one-way ANOVA and Student's $t$ test was used for comparison between treatment groups (Snedecor and Cochran, 1980; Spector et al., 1985).

\section{Results}

From day 115, body mass and testicular and epididymides masses showed marked increases up to 200 days of age (Table 1). During this period, the average concentration of relaxin in peripheral blood plasma ranged from 268 to $484 \mathrm{pg}$ $\mathrm{ml}^{-1}$ (Fig. I). Relaxin concentrations decreased $(P<0.05)$ from the first to third weeks of age but increased thereafter. Relaxin concentrations were at a maximum $(P<0.05)$ between 63 and 77 days of age and decreased thereafter up to 105 days of age. After 175 days, a slight but not significant increase in relaxin was observed and relaxin remained fairly constant thereafter.

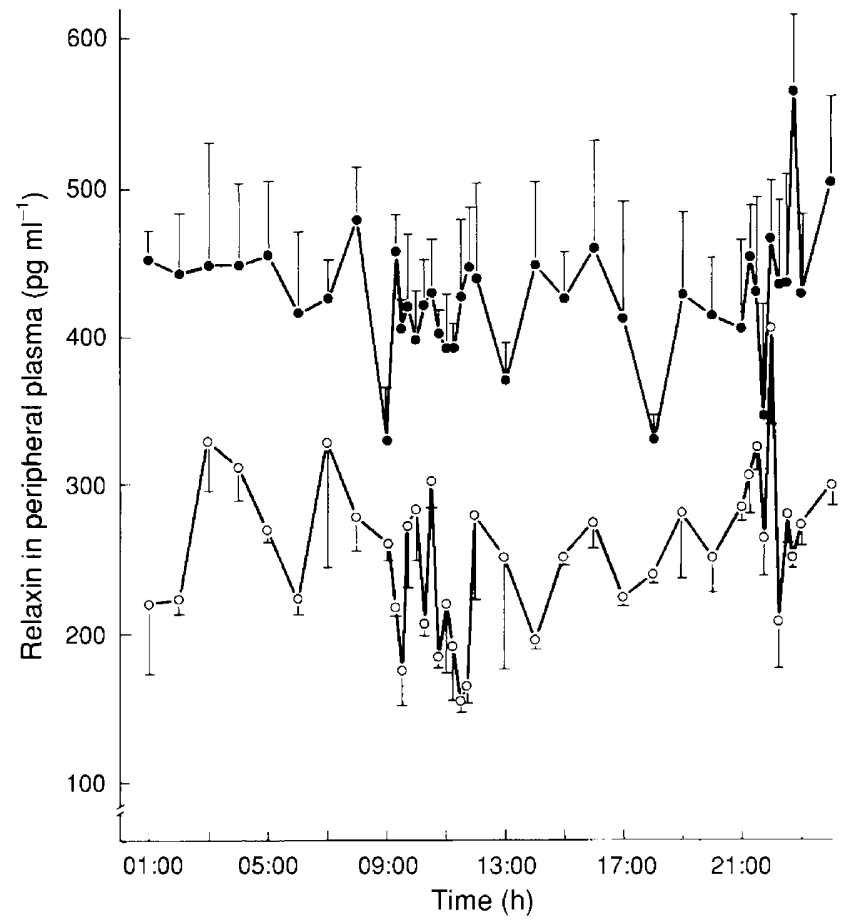

Fig. 2. Sequential concentrations of relaxin in peripheral plasma of boars during $24 \mathrm{~h}$. (O) Prepubertal Yorkshire boars 115 days of age $(n=2)$ and $(\bullet)$ sexually mature Yorkshire boars $>1.5$ years of age $(n=3)$. Samples were taken every hour for $24 \mathrm{~h}$ except during 09:00-12:00 h and 21:00-23:00 h when samples were collected at intervals of $15 \mathrm{~min}$. Values are means \pm SEM.

The data do not support a significant positive correlation between relaxin secretion and testicular development before day 28 , except that there is a negative relationship between these two parameters. The ratios of testicular mass to body mass were $1.06,1.22,2.82$ and $2.78 \mathrm{~g} \mathrm{~kg}^{-1}$ body mass at days $90,115,160$ and 200 , respectively. The negative relationship between plasma relaxin and testicular mass persists even after compensating for changes in testis mass relative to body mass.

The concentrations of relaxin determined from sampling every hour were in the same range as those in samples taken once a week $(P>0.02$, Fig. 2). Relative to within boar mean $24 \mathrm{~h}$ concentrations of relaxin, low relaxin concentrations were observed at 09:00, 13:00 and 18:00 h. These data suggest that relaxin could be secreted in a pulsatile manner at this time in the boar's development. Relaxin concentrations were determined in boars after castration in four age groups. The results (Table 2) show that, independent of age at time of castration, peripheral blood concentrations of relaxin measured during the $48 \mathrm{~h}$ after castration were unaffected by castration. Concentrations of relaxin in peripheral blood decreased ( 325 versus $\left.430 \mathrm{pg} \mathrm{ml}^{-1} ; P<0.05\right)$ in boars when exposed to oestrous sows. Concentrations of relaxin returned to the pre-exposure concentrations during the act of copulation and then declined and remained significantly $(P<0.05)$ lower up to $180 \mathrm{~min}$ after mating but had increased 240 min after mating (Fig. 3).

Administration of hCG to boars aged 90 days resulted in a significant $(P<0.05)$ decrease in relaxin concentrations from $10 \mathrm{~h}$ after hormone treatment (Fig. 4). In contrast, when hCG was administered to older boars (aged 160 days), peripheral 
Table 2. Peripheral plasma concentrations of relaxin $\left(\mathrm{pg} \mathrm{ml}^{-1}\right)$ in Yorkshire boars before and after castration

\begin{tabular}{lcccc}
\hline \multicolumn{4}{c}{ Age (days) } \\
\cline { 2 - 5 } Time $(\mathrm{h})^{*}$ & $\begin{array}{c}90 \\
(n=4)\end{array}$ & $\begin{array}{c}115 \\
(n=2)\end{array}$ & $\begin{array}{c}160 \\
(n=7)\end{array}$ & $\begin{array}{c}200 \\
(n=6)\end{array}$ \\
\hline-12 & $318 \pm 24$ & $284 \pm 34$ & $285 \pm 39$ & $267 \pm 12$ \\
-1 & $291 \pm 41$ & $254 \pm 54$ & $281 \pm 38$ & $298 \pm 17$ \\
+1 & $283 \pm 46$ & $270 \pm 11$ & $269 \pm 49$ & $288 \pm 18$ \\
+6 & $252 \pm 41$ & $288 \pm 61$ & $274 \pm 56$ & $238 \pm 21$ \\
+24 & $340 \pm 33$ & $224 \pm 46$ & $273 \pm 40$ & $249 \pm 23$ \\
+48 & $383 \pm 65$ & $258 \pm 11$ & $230 \pm 45$ & $237 \pm 18$ \\
\hline
\end{tabular}

Values are means \pm SEM.

*Time before and after castration.

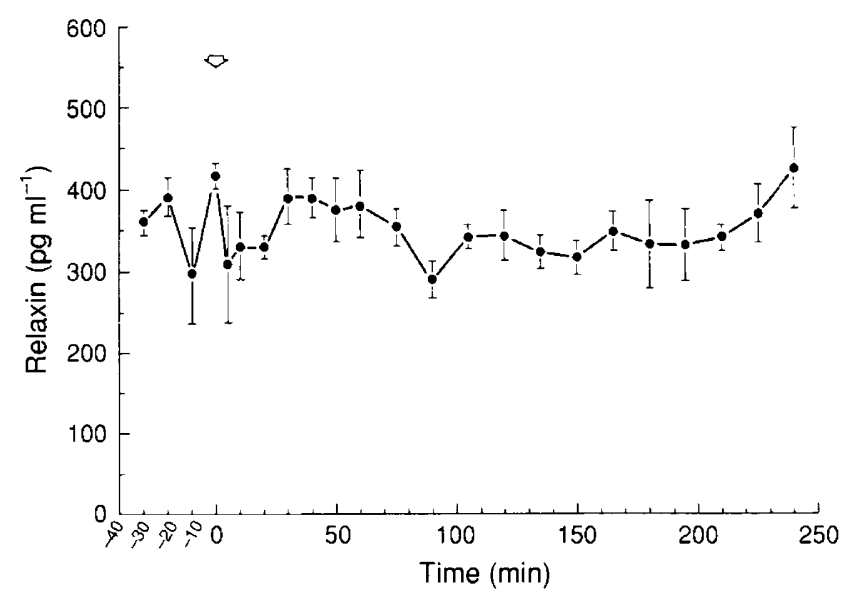

Fig. 3. Relaxin concentrations in peripheral plasma of Yorkshire boars $(n=3)$ before, during and after copulation with sows in oestrus. The arrowhead indicates the time of copulation. Values are means \pm SEM.

relaxin concentrations were unaffected $(P>0.41)$ in comparison with the vehicle-treated controls. The magnitude and duration of endogenous testosterone release in response to exogenously administered hCG was age-dependent. In the 90-day-old boars, testosterone concentrations increased from $3 \mathrm{ng} \mathrm{ml}^{-1}$ to a peak of $18 \mathrm{ng} \mathrm{ml}^{-1} 14 \mathrm{~h}$ after hCG treatment and in 160-day-old boars, testosterone increased from $3.5 \mathrm{ng} \mathrm{ml}^{-1}$ to a peak of $32 \mathrm{ng} \mathrm{ml}^{-1} 14 \mathrm{~h}$ after hCG injection. In contrast to relaxin concentrations, testosterone concentrations increased $(P<0.05)$ soon after the hCG injection and remained consistently higher during the $48 \mathrm{~h}$ after treatment compared with those of diluent-treated controls.

\section{Discussion}

The present study shows that there is an increase in concentrations of relaxin in boar peripheral plasma from 9 to 11 weeks of age compared with earlier and later stages of development. Development of the reproductive tract in these boars was normal and similar to that reported by Allrich et al. (1982). In comparison with previous reports, circulating relaxin concen- trations in this investigation showed no correlation with the development of the testes, seminiferous tubules, Leydig cells and Sertoli cells (Allirich et al., 1982; Colenbrander et al., 1982; van Vorstenbosch et al., 1984; Lunstra et al., 1986). In addition, there was no correlation in the secretion pattern of relaxin with concentrations of testosterone, LH, FSH and oestradiol in peripheral plasma (Allrich et al., 1982; Ford, 1983; Vandlem et al., 1986).

The study reported here indicates that endogenous relaxin in mature boars does not support a diurnal rhythm although it is possible that secretion is of a pulsatile nature. In boars, $\mathrm{LH}$, testosterone and prolactin are secreted into blood in a pulsatile, rather than continuous, manner (Lapwood and Florcurz, 1978; Klindt and Stone, 1984). Anticipation of sexual activity and copulation affects relaxin concentrations. However, after exposure of boars to sows in oestrus, relaxin concentrations in peripheral blood decreased and remained significantly lower for $4 \mathrm{~h}$ after mating. A sharp increase in corticosteroid, testosterone and LH blood concentrations after copulation in aggressive boars was reported by Ellendorff et al. (1975) and Liptrap and Raeside (1978).

During prepubertal development, sequential blood sampling revealed that plasma relaxin concentrations are low and fluctuate in a manner similar to that seen in mature boars. Furthermore, frequent blood sampling during $24 \mathrm{~h}$ revealed no consistent pattern of pulsatile or diurnal secretion. There was a lack of association of relaxin immunoreactivity to growth of the reproductive tract in boars. Although hCG treatment abruptly increased testosterone concentrations in peripheral plasma, relaxin remained at basal concentrations for $54 \mathrm{~h}$. Low circulating concentrations of immunoreactive relaxin in boars, as determined by the R6 antibody, may represent specific relaxin binding or binding of an unidentified ligand. These studies revealed no striking hormone-dependent effects on relaxin production and secretion into peripheral blood of boars. The role of relaxin in boars appears to be more complex than predicted. It is emphasized that relaxin concentrations are three to four times higher in the seminal plasma than in blood plasma of mature boars (Juang et al., 1990); thus, changes in hormone concentrations in peripheral blood are not as descriptive in males as in pregnant, or hysterectomized, females.

The source of relaxin in the male reproductive tract remains controversial. Relaxin immunoactivity was reported in the prostate gland of armadillos, humans and rats (Cameron et al., 1982; Kendall et al., 1982; Yki-Jarvinen et al., 1983). Lobb and Porter (1995) reported finding mRNA encoding relaxin in boars and immunoactivity for relaxin was reported in boar seminal vesicles by Kohasaha et al. (1992). Although Leydig cells of boar testes contain mRNA encoding relaxin (Lobb et al., 1995), hCG treatment of intact boars in the study reported here did not increase relaxin secretion but did sustain an increased testosterone secretion. Thus, gonadotrophin treatment appears to have little effect on expression of the relaxin gene by Leydig cells in immature and mature boars. In sows, the corpora lutea of the ovaries are a major source of relaxin during the oestrous cycle and pregnancy (Anderson et al., 1973). Concentrations of relaxin in blood remain low $\left(<1 \mathrm{ng} \mathrm{ml}^{-1}\right)$ during the oestrous cycle but increase steadily to peak concentrations (>60 ng $\mathrm{ml}^{-1}$ ) during late pregnancy, but without a distinct pattern of pulsatile change in hormone secretion (Sherwood and 
(a)

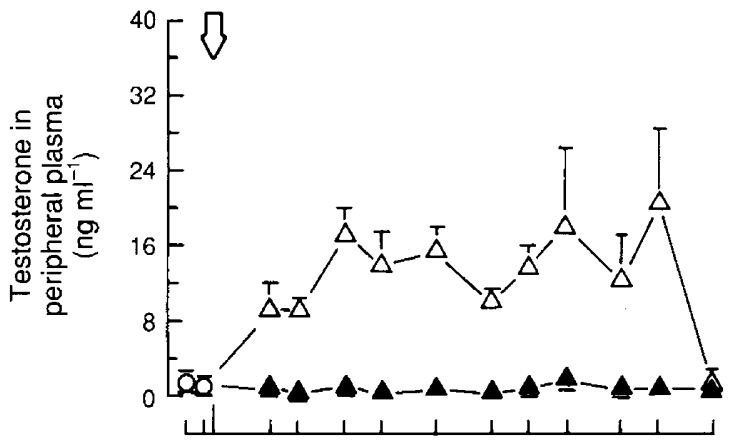

(b)

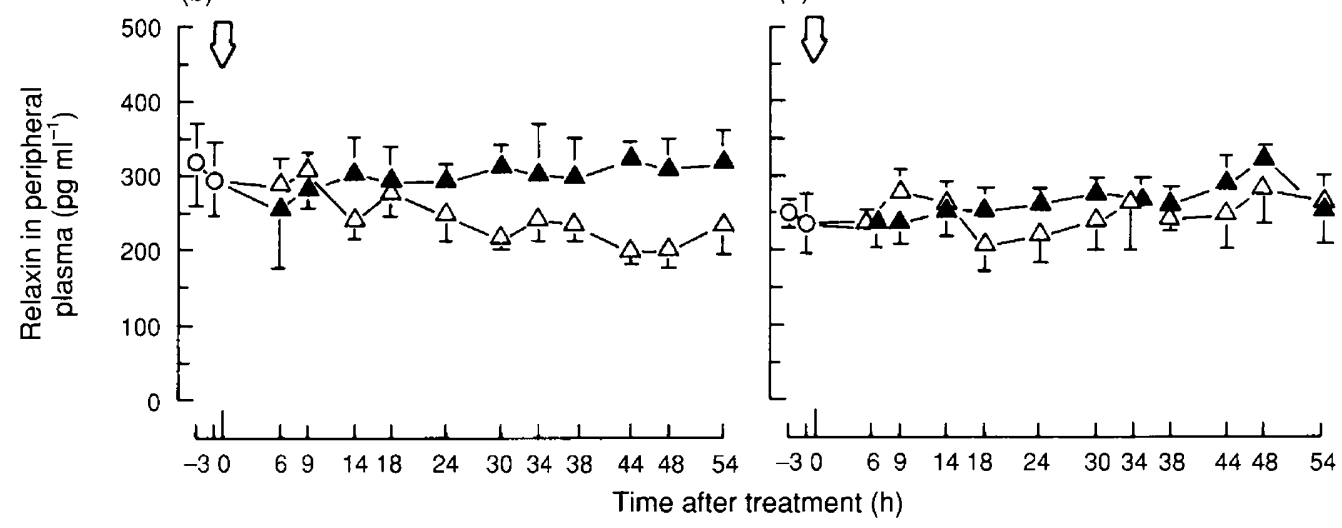

(c)

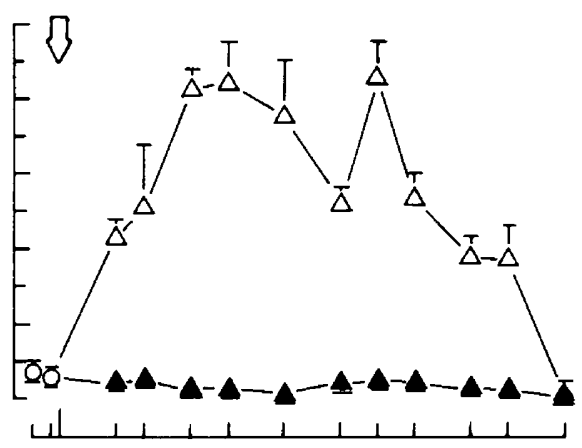

(d)

Fig. 4. Concentrations of $(a, c)$ testosterone and $(b, d)$ relaxin in peripheral plasma of Yorkshire boars given an i.m. injection of $(\triangle) 4000$ iu hCG $(n=4)$ or $(\mathbf{\Delta}) 3 \mathrm{ml}$ PBS $(n=4)$ at $(\mathrm{a}, \mathrm{b}) 90$ days of age or $(\mathrm{c}, \mathrm{d}) 160$ days of age. Values are means \pm SEM. The arrows indicate the time of administration of hCG or PBS.
Rutherford, 1981; Felder et al., 1986). In contrast to the lack of effect of gonadotrophin treatment on relaxin secretion in the boars in the present study, $\mathrm{LH}$ and prolactin increase relaxin production by ageing porcine corpora lutea in vitro (Huang et al., 1992), and in vivo prolactin maintains relaxin secretion for 10 days in hypophysectomized-hysterectomized gilts (Li et al., 1989). In addition, expression of the relaxin gene in corpus luteum of sows appears during the oestrous cycle, pregnancy and lactation (Bagnell et al., 1990). In the uterine endometrium of sows, expression of the relaxin gene and relaxin immunostaining have been detected between days 10 and 20 of the oestrous cycle in pregnant and nonpregnant animals (Knox et al., 1994). Thus, there are marked differences in the expression of the relaxin gene and relaxin production during the different reproductive states in boars and sows. Relaxin concentrations were similar between intact and recently castrated boars in the present study, supporting the hypothesis that the testis might be a target tissue rather than a source of relaxin (Yamamoto and Bryant-Greenwood, 1981).

The results of the present study indicate that peripheral blood concentrations of relaxin in boars remain low $(<500 \mathrm{pg}$ $\mathrm{ml}^{-1}$ ) before puberty and are generally unrelated to prepubertal development and sexual maturity, and are three to four times lower than those found in seminal plasma. Agedependent increases in gonadotrophin-induced testosterone secretion were without effect on relaxin secretion.
The authors thank M. E. Shell and C. R. Bohnker for excellent technical assistance. Porcine relaxin antiserum was generously provided by B. G. Steinetz (New York University Medical Center, Tuxedo, NY). This study was presented in part at the 21st Annual Meeting of the Society for the Study of Reproduction, Pullman, WA (Abstract 102) and the 80th Annual Meeting of American Society of Animal Science, New Brunswick, NJ (Abstract 423). These studies were supported in part by US Department of Agriculture, NRICGP competitive Grant 93-37203-8965. All experiments in this report were performed following the standards established by the Animal Welfare Act and the NIH Guide for the Care and Use of Laboratory Animals, Publication $85-23$ and approved by the lowa State University Committee on Animal Care. Journal Paper no. J-15848 of the Iowa Agriculture and Home Economics Experiment Station, Ames, IA (Projects 2443, 2444, 3223). The mention of trade names or companies does not constitute an implied warranty or endorsement by the USDA, lowa State University, or the authors.

\section{References}

Allich RD, Christenson RK, Ford JJ and Zimmerman DR (1982) Puberal development of the boar: testosterone, estradiol-17ß, cortisol and $\mathrm{LH}$ concentration before and after castration at various ages Journal of Animal Science 55 1139-1146

Anderson LL (1987) Regulation of relaxin secretion and its role in pregnancy Advances in Experimental Medicine and Biology 219 421-463

Anderson LL, Ford JJ, Melampy RM and Cox DF (1973) Relaxin in porcine corpora lutea during pregnancy and after hysterectomy American Journal of Physiology 225 1215-1219 
Anderson MB, Cooado-Torres M and Vaupel MR (1986) Absence of relaxin immuno-staining in the male reproductive tracts of the rat and mouse Journal of Histochemistry and Cytochemistry 31 391-397

Bagnell CA, Tashima L, Tsark W, Ali SM and McMurtry JP (1990) Relaxin gene expression in the sow corpus luteum during the cycle, pregnancy, and lactation Endocrinology 126 2514-2520

Cameron DF, Corton GL and Larkin LH (1982) Relaxin-like antigenicity in the armadillo prostate gland Annals of the New York Academy of Sciences $\mathbf{3 8 0}$ 231-240

Colenbrander B, van de Wiel DFM, van Rossum-kok CMJE and Wensing CJG (1982) Male sexual development. In Control of Pig Reproduction pp 3-24 Eds DIA Cole and GR Foxcroft. Butterworth Science Press, London

Dubois MP and Dacheux JL (1978) Relaxin, a male hormone? Immunocytologic localization of a related antigen in the boar testis Cell and Tissue Research 187 201-214

Ellendorff F, Parvizi N, Pomerantz DK, Kartjen A, Konig A, Smidt D and Elsaesser F (1975) Plasma luteinizing hormone and testosterone in the adult male pig: 24 hour fluctuation and the effect of copulation Journal of Endocrinology 67 403-410

Felder KJ, Molina JR, Benoit AM and Anderson LL (1986) Precise timing for peak relaxin and decreased progesterone secretion after hysterectomy in the pig Endocrinology 119 1502-1509

Ford JJ (1983) Serum estrogen concentration during postnatal development in the male pig Proceedings of the Society of Experimental Biology and Medicine 174 160-164

Ford JJ and Maurer RR (1978) Simple technique for chronic venous catheterization of swine Laboratory Animal Science 28 615-618

Ford JJ, Christenson RK and Mauer RR (1980) Serum testosterone concentrations in embryonic and fetal pigs during sexual differentiation Biology of Reproduction 23 583-587

Huang CJ, Li Y, Stromer MH and Anderson LL (1992) Synergistic effects of insulin-like growth factor I and gonadotrophins on relaxin and progesterone secretion by ageing corpora lutea of pigs Journal of Reproduction and Fertility $96415-425$

Juang HH, Musah AI, Schwabe C and Anderson LL (1989) Effect of relaxin and antirelaxin serum on porcine sperm motility Animal Reproduction Science 20 $21-29$

Juang HH, Musah AI and Anderson LL (1990) Immunoactive relaxin in boar seminal plasma and its correlation with sperm motility Animal Reproduction Science 22 47-53

Kendall JE, Smith RG, Shih L, Webb PD and Tate WH (1982) Characterization of prostate relaxin. In Biology of Relaxin and Its Role in the Human pp 363-366 Eds M Bigazzi, FC Greenwood and F Gasparri. Elsevier Press, New York

Klindt J and Stone RT (1984) Porcine growth hormone and prolactin concentration in the fetus and secretory patterns in the growing pig Growth $\mathbf{4 8}$ I-15

Knox RV, Zhang Z, Day BN and Anthony RV (1994) Identification of relaxin gene expression and protein localization in the uterine endometrium during early pregnancy in the pig Endocrinology 135 2517-2525

Kohasaha T, Takahara H, Sasada H, Kawarasaki T, Bamba K, Masaki J and Tagami $S$ (1992) Evidence for immunoreactive relaxin in boar seminal vesicles using combined light and electron microscope immunocytochemistry Journal of Reproduction and Fertility 95 397-408

Lapwood KR and Florcurz SV (1978) Luteinizing hormone and the testosterone secretory profiles of boar: effects of stage of sexual maturation Theriogeneology $10293-306$
Lessing JB, Brenner SH, Schoenfeld C, Sarosi P, Goldsmith LT, Amelar R, Dubin L and Weiss $G$ (1986) The effect of relaxin on human spermatozoa Journal of Reproductive Medicine 44 406-409

Li Y, Molina JR, Klindt J, Bolt DJ and Anderson LL (1989) Prolactin maintains relaxin and progesterone secretion by aging corpora lutea after hypophysial stalk transection or hypophysectomy in the pig Endocrinology 124 1294-1304

Liptrap RM and Raeside JI (1978) A relationship between plasma concentration and corticosteroid during sexual and aggressive behaviour in the boar Journal of Endocrinology 76 75-85

Lobb DK and Porter DG (1995) PCR studies of relaxin in the male Proceedings of the 2nd international Congress on the Hormone Relaxin. Adelaide, South Australia pp 579-587 Eds AH MacLennan, GW Tregear and GD BryantGreenwood. World Scientific Publishing Co. Pte. Ltd, Singapore

Lobb DK, Yeo JE, Raeside JI and Porter DG (1995) Identification of the Leydig cell as a site of relaxin synthesis in the boar Journal of Reproduction and Fertility Abstract Series 15 Abstract 15

Lunstra DD, Ford JJ, Christenson RK and Allrich RD (1986) Changes in Leydig cell ultrastructure and function during puberal development in the boar Biology of Reproduction 34 145-158

Park JM, Ewing K, Miller F, Friedman CI and Kim MH (1988) Effects of relaxin on the fertilization capacity of human spermatozoa American Journal of Obstetrics and Gynecology 158 974-979

Pupula M, Quinn P and MacLennan A (1986) The effect of porcine relaxin on the fertilization of mouse oocytes in vitro Clinical Reproduction and Fertility 4 383-387

Schwabe C (1983) $N$ - $\alpha$-Formyl-tyrosyl-relaxin: a reliable tracer for relaxin radioimmunoassay Endocrinology 113 814-815

Sherwood OD and Rutherford JE (1981) Relaxin immunoactivity levels in ovarian extracts obtained from rats during various reproductive states and from adult cycling pigs Endocrinology 108 1171-1177

Snedecor GW and Cochran WG (1980) Statistical Methods (7th Edn) pp 593 lowa State University Press, Ames

Spector PC, Goodnight JH, Sall JP and Sarke WS (1985) General Linear Regression. In SAS User's Guide, Statistics (5th Edn) pp 433-506. SAS Institute Inc., Cary, NC

Vandlem JL, McNamaram M, Petit R and Hennen G (1986) Developmental changes in gonadotrophins and testicular gonadotrophin receptors in the pig from neonatal to adult life Journal of Endocrinology 111 301-308

van Vorstenbosch CJAHV, Colenbrander E, Spek B and Wensing CJG (1984) Sertoli cell development of pig testis in the fetal and neonatal period Biology of Reproduction 31 565-577

Weiss G (1989) Minireview: relaxin in the male Biology of Reproduction 40 197-200

Weiss G, Goldsmith L, Schoenfeld C and D'Elettom R (1986) Partial purification of relaxin from human seminal plasma American Journal of Obstetrics and Gynecology 154 749-755

Yamamoto S and Bryant-Greenwood GD (1981) The isolation of relaxin from boar testis. In Relaxin pp 71-74 Eds GD Bryant-Greenwood, HD Niall and FC Greenwood. Elsevier/North-Holland Press, Amsterdam

Yki-Jarvinen $\mathbf{H}$, Wahlstrom $\mathbf{T}$ and Seppala $\mathbf{M}$ (1983) Immunohistochemical demonstration of relaxin in the genital tract of men Journal of Reproduction and Fertility 69 693-695 